Ю.О. Камак ${ }^{1}$, С.О. Нестеренко ${ }^{1}$, С.В. Рудніченко ${ }^{1}$, Р.М. Чигрин ${ }^{2}$

${ }^{1}$ Державний науково-дослідний інститут випробувань і сертифікаиії озброєння та військової техніки, Чернігів

${ }^{2}$ Харківський національний університет Повітряних Сил ім. І. Кожедуба, Харків

\title{
ЗАСТОСУВАННЯ ЙМОВІРНІСНИХ МЕРЕЖ ДОВІРИ ДЛЯ БАГАТОКРИТЕРІАЛЬНОГО ОЦІНЮВАННЯ ПОКАЗНИКІВ ЯКОСТІ ОЗБРОЄННЯ ТА ВІЙСЬКОВОЇ ТЕХНІКИ
}

В статті проводиться аналіз прочесу конкурентного вибору зразків озброєння та військової техніки з метою вибору зразка озброєння та військової техніки, найкращого за визначеним показником якості з ряду альтернативних. Проведено аналіз існуючого методичного апарату вирімення поставленої проблеми та запропоновано використання апарату байєсівської мережі довіри для вирішення задачі вибору якісного зразка озброєння та військової техніки. Наведено аналіз програмних засобів для моделювання байєсівських мереж довіри. Запропонована процедура прийняття рішення щчодо вибору зразка за ймовірнісними критеріями в умовах недостатньої визначеності.

Ключові слова: озброєння та військова техніка, показник якості, особа, яка приймає рішення, байєсівська мережа довіри.

\section{Вступ}

Постановка проблеми. Воєнна доктрина України [1] ставить перед вітчизняним військовопромисловим комплексом задачу “...прийняття на озброєння принципово нових зразків [озброєння та військової техніки (ОВТ)], розроблених на основі сучасних технологій”. Отже, ключовою проблемою розробки та прийняття на озброєння зразка ОВТ $є$ його висока ефективність, яка тут розуміється як здатність зразка ОВТ гарантовано досягати поставлених бойових цілей при його штатному використанні. В свою чергу, ефективність є наслідком достатньої якості зразка ОВТ, відносно якої в [2-3] використовується також синонім “високий технічний рівень”. Висока якість ОВТ забезпечується виконанням процедур та положень, регламентованих на державному рівні рядом Законів України [4-5].
Ця складна та відповідальна задача в організаційно-технічному плані вирішується 3 урахуванням вимог ряду вітчизняних та міжнародних стандартів.

Так, стандарт [6] цілком логічно пов'язує контроль якості продукції з необхідністю виконувати їх порівняльні дослідження, в тому числі при проведенні різного рівня випробувань.

Більш повна інформація про засоби забезпечення достатньої якості продукції наводиться в стандарті [7], який регламентує порядок виконання дослідно-конструкторських робіт (ДКР) із створення або модернізації техніки, в тому числі військової. Як і в [6], стандарт [7] вирішення задачі одержання потрібної високої якості (технічного рівня) ОВТ обумовлює необхідність проводити регулярні експериментальні дослідження, місце яких в ДКР показано на рис. 1.

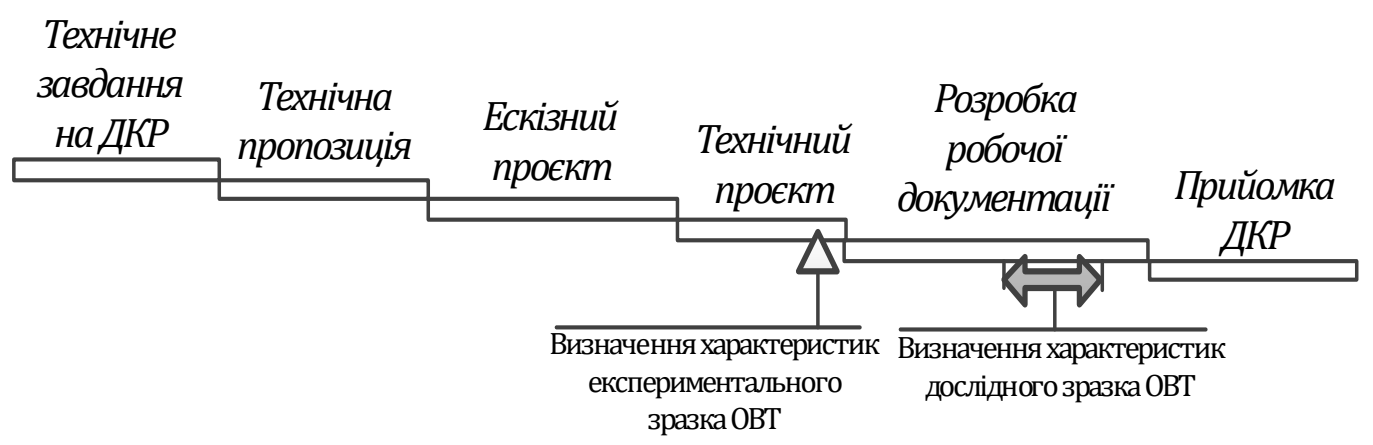

Рис. 1. Місце визначення фактичних характеристик продукції при виконанні ДКР Джерело: розроблено авторами за даними [5]. 
Закони України “Про оборонні закупівлі” [4] та "Про публічні закупівлі" [5] вимагають додержання конкурентного принципу при формуванні державного оборонного замовлення та визначенні конкретних зразків ОВТ, які будуть ставитись на озброєння.

Важливу роль у формуванні переліку якісних зразків ОВТ відіграють сертифікаційні базиси. Наприклад, для авіаційної галузі принципи їх формування регламентуються [8]. Також, зокрема, в [9] дається таке визначення:

“3.1 Сукупність процедур сертифікації... полягає в ... уникненні надходження (постачання) у війська ... зразків ОВТ, що не відповідають вимогам нормативних документів до якості”.

Необхідною запорукою додержання конкурентного принципу у відборі якісного ОВТ є використанні релевантних процедур та принципів порівняльних досліджень зразків ОВТ.

Порівняльне дослідження пари зразків ОВТ формально можна описати трійкою множин рівної потужності $N:\langle A, B, C\rangle$,

де $A=\left\{a_{i}\right\} \mid i \in[1 \ldots N]$ - множина значень параметрів зразка $A$, заданих для перевірки замовником порівняльного дослідження;

$$
B=\left\{b_{i}\right\} \mid i \in[1 \ldots N]-\text { множина значень парамет- }
$$

рів зразка $\mathrm{B}$, також заданих для перевірки замовником порівняльного дослідження;

$$
C=\left\{\left(a_{i}, b_{i}\right)\right\} \mid i \in[1 \ldots N] \quad-\quad \text { множина } \quad \text { пар }
$$

відповідності значень параметрів зразків ОВТ $A$ та $B$ виявлених в ході порівняльного експериментального дослідження.

Для спрощення аналізу величини $a_{i}, b_{i}$ звичайно піддають операціям масштабування та нормування. Це дозволяє перейти до їх безрозмірного виду, що надає можливість порівняння параметрів, навіть різних за фізичною природою. Крім того, всі параметри можливо сформулювати таким чином, щоб позитивний ефект досягався, припустимо, саме при їх збільшенні, а не зменшенні.

Кожен елемент множини $C$, який є парою $\left(a_{i}, b_{i}\right)$ заявленого та діагностованого значень $i$-го параметру, дає змогу визначити за певною функцією $f_{i}$ значення оцінки $r_{i}$ цього параметру:

$$
r_{i}=f_{i}\left(a_{i}, b_{i}\right) .
$$

Для різних параметрів можуть застосовуватись різні функції $f_{i}$, які можуть повертати значення різних типів, як кількісних, так і якісних. Разом 3 тим, без втрати загальності в аналізі, можна вважати, що вироблення оцінки $r_{i}$ через співставлення $a_{i}, b_{i}$ може виконуватись, принаймні, за способами оцінювання, зображеними на рис. 2 .
Ці приклади показують, що при оцінюванні результатів випробування неможливо гарантовано уникнути ситуацій їх часткової невизначеності, або нечіткості (розмитості). Подібна особливість технічного діагностування параметрів досліджуваних зразків ОВТ вимагає застосовувати для їх оцінювання більш адекватну методологію.

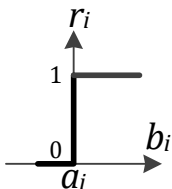

a

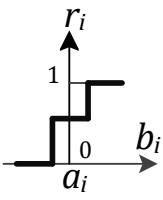

б

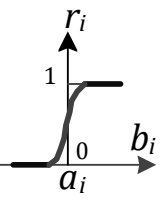

B
Рис. 2. Способи оцінювання параметру зразка ОВТ за результатами його діагностування в результаті експериментального дослідження

a - дискретна двохальтернативна оцінка;

б - нечітка дискретна багатоальтернативна оцінка; в - безперервна нечітка оцінка

Джерело: розроблено авторами за даними [15].

Складні економічні та технічні умови, в яких відбувається зараз розробка та постачання Збройним Силам України ОВТ, значною мірою виключила 3 цього процесу фактор конкурентної боротьби за одержання оборонного замовлення. Світовий досвід [10] показує, що без цього неможливо досягти реально високих тактико-технічних показників військової техніки та засобів одержання перемоги над противником.

За умови існування конкуренції між розробниками, ідеалізована часова послідовність конкурентної боротьби розробників за одержання оборонного замовлення могла б бути такою:

$$
\begin{aligned}
& D_{0}=\left\{D_{j}\right\}, j=1, n_{0} ; \\
& D_{1}=\left\{D_{j}\right\}, j=1, n_{1}, \text { де } n_{1}<n_{0} ; \\
& \cdots \\
& D^{*}=\left\{D_{j}^{*}\right\}, j=1 .
\end{aligned}
$$

На початку для вибору надається множина зразків ОВТ конкретного класу/типу, потужність якої поступово знижується з $\left|D_{0}\right|$ до $\left|D^{*}\right|$ за рахунок поступового вибуття розробників 3 конкурентної боротьби за підсумками конкурсів, в кожний етап (момент) умовних конкурсів $K_{i}$, мета яких полягає у виборі найкращих зразків ОВТ з множини тих, які приймають участь в черговому конкурсі. В моментах $K_{i}$ повинен виконуватись вибір кращих зразків, але це завдання вимагає визначення формального правила порівняння двох зразків.

Припустимо, зразок $S_{1}$ характеризується множиною результатів випробування $R_{1}=\left\{r_{1 i}\right\} i \in[1, N]$,

а конкуруючий зразок $S_{2}-$ множиною 
$R_{2}=\left\{r_{2 i}\right\} i \in[1, N]$, причому $N$ має величину порядку $10^{1}$. Задача вибору між $S_{1}$ та $S_{2}$ в такій постановці вирішується шляхом порівняльного аналізу множин $R_{1}$ та $R_{2}$ і відома як задача багатокритеріального вибору [11].

Аналіз досліджень і публікацій. Задача прийняття рішення в умовах невизначеності, при проведенні конкурсів, може вирішуватись різними способами. Треба приймати до уваги, що невизначеність при прийнятті рішення може бути класифікована на наступні типи:

- стохастичну (коли є інформація про розподіл імовірностей на множині результатів);

- поведінкову (коли є інформація про вплив поведінки учасників конкурсу на результати вибору);

- природну (коли є інформація тільки про діагностуванні результати, але неповністю відомо, який існує зв'язок між результатами оцінки параметрів та можливими рішеннями щодо вибору);

- апріорну (коли інформація про можливі наслідки прийняття рішень неповна або відсутня).

3 цієї множини типів невизначеності при вибоpi зразків ОВТ стохастична невизначеність, скоріше за все, має бути виключена з розгляду з тої причини, що порівняльні дослідження певного зразка ОВТ в його життєвому циклі є відносно нечастою подією. Внаслідок цього важко чекати, що за результатами таких досліджень на даний момент можна буде сформувати статистично репрезентативну вибірку результатів, за якими можна побудувати частотні розподіли ймовірностей.

Нехай на розгляд особи, що приймає рішення (ОПР) подається множина зразків ОВТ $S^{R}=\left\{S_{j}\left(R_{j}\right)\right\} \mid j \in[1 \ldots M] ; M>1, \quad$ і треба вибрати кращий зразок $S^{*}$ шляхом математичної обробки векторів $R_{j}$ результатів оцінювання параметрів зразків, які порівнюються.

Відомі роботи, в яких вибір тих чи інших варіантів виконується різного роду комбінуванням значень параметрів $r_{i}$ та їх вагових коефіцієнтів, які несуть інформацію про відносну важливість $r_{i}$. Критерії, які використовуються в цих роботах, відомі як критерій “недостатнього обгрунтування", “найбільш обережного вибору”, Гурвіца [12], “максімаксу” та подібних до них.

В роботі [13] запропоновано для кожної альтернативи $3 S^{R}$ визначити найбільший ризик (неодержану корисність)

$$
D_{j}=\max _{i}\left(u_{j i}\right) \mid j \in 1 \ldots M, i \in 1 \ldots N
$$

Виграшним буде той зразок, для якого $D_{j}$ буде мінімальним:

$$
S^{*}=S_{k}, D_{k}=\min \left(D_{j}\right), j=1 \ldots M .
$$

В роботах [14-15] описується підхід до вибору альтернатив, який одержав назву методу аналізу ієрархій (MAI).

В цьому методі пропонується структурувати проблему вибору у вигляді ієрархії. У простих випадках ієрархія будується з вершини (мети порівняння), через проміжні рівні-критерії (технікоекономічні параметри) до самого нижнього рівня, який в загальному випадку містить набір альтернатив, серед яких ОПР хоче зробити вибір. Після ієрархічного опису проблеми встановлюються пріоритети критеріїв.

Основою визначення пріоритетів критеріїв вибору виступає процедура попарного порівняння відносної важливості (інтенсивності впливу) критеріїв, яку виконує або ОПР, або експерт. Якщо вважати справедливою аксіому антисиметричності порівнянь (якщо критерій $A$ більш важливий за $B$, припустимо, у $C$ разів, то важливість $B$ повинна становити $C^{-1}$ важливості $A$ ), то як результат подібного порівняння одержується квадратна матриця попарних порівнянь (МПП), яка за структурою не може бути ніякою іншою, аніж антисиметричною. Це означає, що її елементи знаходяться між собою у співвідношенні $m_{i j}=m_{i j}^{-1}, m_{i j}=1, \mid i, j \in 1 \ldots k$, де $k-$ кількість параметрів, які порівнювались.

Для визначення пріоритетів вибору на підставі МПП в методі МАI використовується математичний апарат лінійної алгебри, застосовуваність якого автор цього методу $T$. Сааті обгрунтовує, наприклад, в [16]. Конкретно, за [16], шукані числові міри пріоритетів критеріїв мають бути пропорційні компонентам головного власного вектору [17] МПП. Для знаходження цього вектору застосовуються стандартні математичні методи.

3 наведених вище відомостей та проведеного аналізу ясно, що ключовим завданням конкурентного вибору можна назвати прийняття обгрунтованого рішення щодо вибору найкращого зразка ОВТ 3 ряду альтернативних. За умови використання для вибору саме показників якості вирішення сформульованого тут завдання на даний момент ще не запропоновано. Розглянуті вище стандарти та нормативні документи не містять відомостей (і навіть рекомендацій) про раціональні алгоритми вибору зразків ОВТ за показниками якості. Натомість, визначення якості заміняється в них порівнянням наборів параметрів, результат якого неоднозначний 3 огляду на дві серйозні труднощі:

- принципова апріорна неповна визначеність компонентів вектору $R=\left\{r_{i}\right\}$, яка витікає 3 природи методів експериментального оцінювання якості зразків ОВТ; 
- багатокритеріальність процесу порівняння зразків при визначенні кращого.

Порівняльний аналіз описаних вище методів показує, що всі вони тим чи іншим способом спираються на те, чому віддає перевагу ОПР, не виключаючи вибір самого методу визначення альтернативи при виборі. Тобто, елемент суб'єктивності присутній у всіх них.

Друга загальна риса всіх розглянутих методів (i багатьох з тих, які залишились поза розглядом) полягає в тому, що їх автори по суті пропонують різні методи згортки множини з багатьох порівнюваних критеріїв в один. Тим самим прийняття рішення в умовах апріорної невизначеності штучно підміняється прийняттям рішення в умовах повної визначеності, досягнутої, щоправда, за рахунок внесення в результат певної суб'єктивності. За допомогою розглянутих методів неможливо знайти т. зв. “правильне”, або “об'єктивне” рішення, яке не залежало б від персональних уподобань або упередженості ОПР, та таких рішень найчастіше просто не існує. Цінність їх в наданні ОПР інформації про варіанти вибору, бажано $з$ поясненням наслідків прийняття різних варіантів вибору. Таким чином, всі методи, які використовують різноманітні способи згорток $є$ певним чином умовними, такими, результати використання яких не можна вважати цілком об'єктивними.

Мета цієї роботи полягає у викладенні перспективного способу оцінки інтегрального показника якості зразка ОВТ для прийняття обгрунтованого рішення про вибір найкращого зразка з ряду альтернативних.

\section{Виклад основного матеріалу}

Задачі багатокритеріального аналізу несуть в собі протиріччя та неповну визначеність в самій своїй постановці [11]. Подібне протиріччя усвідомлюється науковцями з самого початку, тому згадані методи розцінюються не як імперативні, а, скоріше, як рекомендаційні.

Разом 3 тим, глибоке осмислення фундаментальних гносеологічних та математичних аспектів відображення в свідомості людини нечіткої інформації, яке відбулося у другій половині ХХ ст. [16; 18-19] дозволили зробити висновок, що велика кількість практичних проблем може бути успішно вирішена, якщо розширити трактовку поняття ймовірності.

Зараз в науці існує три основних інтерпретації ймовірності.

Частотна інтерпретація. Імовірність події в цьому поданні визначається як гранична частота виникнення цієї події в безкінечній кількості випробувань. Наприклад, імовірність аверсу в одному кидку монети - це частка аверсів у безкінечній кількості кидків монети.
Інтерпретація через переваги. Імовірність події в цьому поданні визначається фізичними, об'єктивними властивостями об'єкту або процесу, який генерує подію. Наприклад, імовірність випадання реверсу при одному кидку монети залежить від фізичних властивостей монети, таких як плоска симетрична форма і дві їі сторони.

Суб'єктивістська інтерпретація. Уявлення про частоту та їі сходимість до ймовірності відомі як об'єктивістські, оскільки вони припускають, що ймовірність є об'єктивною властивістю фізичного миру. У суб'єктивістському поданні, також відомому як Байесівська інтерпретація, імовірність події $€$ мірою суб'єктивної упевненості експериментатора в те, що подія відбудеться. Хоча названі три інтерпретації ймовірності $\epsilon$ теоретичними і можуть бути предметом дискусій, вони мають серйозні наслідки для практики аналізу рішень. Як показує практика, об'єктивістські підходи мало підходять для рішення більшості реальних проблем.

Суб'єктивістська точка зору інтерпретує ймовірність як міру особистої впевненості, яка може варіюватися у різних людей. Ця точка зору підкріпляється математичним правилом корекції ймовірності, яка виникає при одержанні нових спостережень (теорема Байеса). Відома формула Байєса [21] дає можливість обчислити нове (апостеріорне) значення ймовірності події $A$ після врахування нової інформації (одержання “додаткового знання”) про результат іншої події $B$, логічно (або причинно) зв'язаної 3 подією $A$. При цьому ймовірність події $A$ до одержання інформації про подію $B$ (апріорна) відома. Формула Байєса [21] для обчислення умовної ймовірності:

$$
P(A \mid B)=\frac{P(A) \cdot P(B \mid A)}{P(B)},
$$

де $P(A \mid B)$ - ймовірність події $A$ за умови, що подія $B$ відбулася;

$P(A)$ - апріорна ймовірність події $A$;

$P(B \mid A)$ - ймовірність події $B$ за умови, що подія $A$ відбулася;

$P(B)$ - апріорна ймовірність події $B$.

Теореми про обмеження доводять [21], що якщо теорема Байєса використовується для оновлення ступеня переконаності $p$, то $p$ буде сходитися до граничної частоти незалежно від фактичного значення початкового ступеня переконаності (за умови, що $p \neq 0$ і $p \neq 1)$. Хоча ці теореми дають гарантії в безкінечності, на практиці сходимість швидка, а розумне призначення первинної апріорної ймовірності робить сходимість ще швидшою. Суб'єктивістський підхід дозволяє ефективно поєднувати в розрахунках як частотні дані, так і знання 
експертів. Частотні ймовірності можуть бути одержані з баз даних, можуть бути засновані на експертних оцінках або їх комбінації.

Викладена тут концепція дозволяє побудувати системи оцінки та порівняння зразків ОВТ, базуючись на показниках їх якості, використовуючи комбінації частотних даних з експертними оцінками.
Науковим підгрунтям для побудови подібних систем оцінки є апарат байєсівських мереж довіри (БМД), математично обгрунтований, наприклад, в [21].

Байєсівська мережа довіри (БМД) є орієнтованим ациклічним графом (рис. 4).

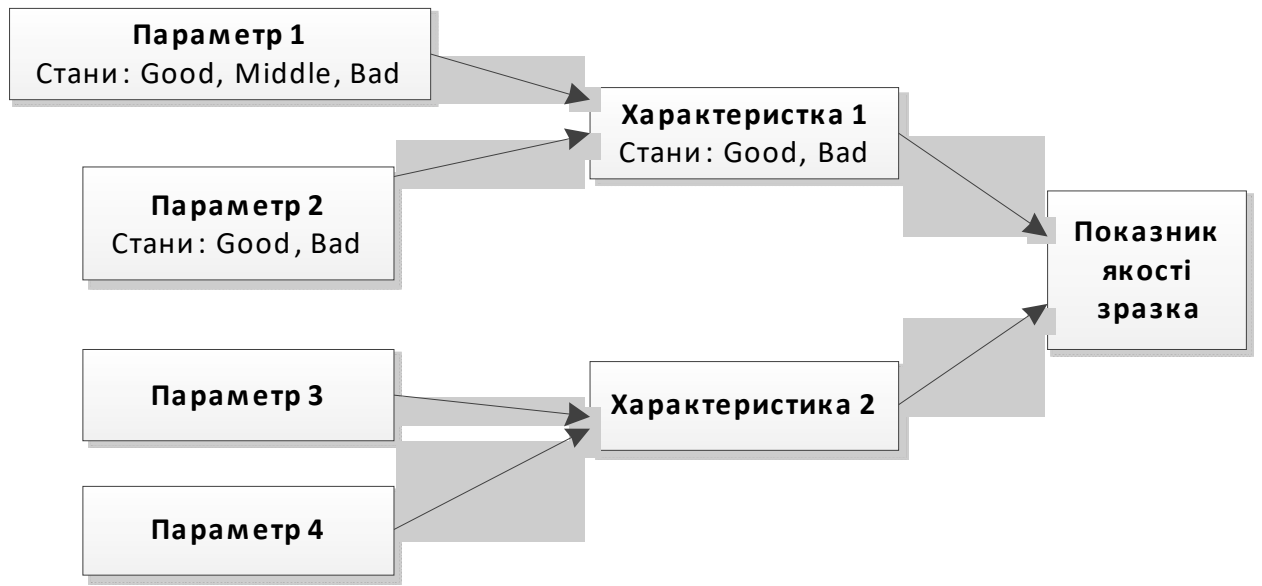

Рис. 4. Приклад Байєсівської мережі довіри Джерело: розроблено авторами.

Вузли цього графу є образами ймовірнісних величин 3 притаманними кожній 3 них апріорними розподілами ймовірності відносно станів (значень), які здатна приймати ця величина.

Параметрами тут вважаються числові та якісні властивості зразка ОВТ, фактично це $R=\left\{r_{i}\right\} \mid i \in[1 \ldots N]$, формула (1). Ця множина звичайно задається в ТТХ зразка ОВТ, в експлуатаційній документації на нього і як результат певних експериментів (випробувань) із зразком ОВТ.

Множина ребер БМД відображає думку ОПР про наявність причинно-наслідкових та/або логічних зв'язків між вузлами. Якщо ребро наявне, то вузол-нащадок (наприклад, “Характеристика 1") $€$ залежним від вузлів-предків ("Параметр 1" та "Параметр 2”). Це означає, що зміна стану вузлівпредків міняє розподіл імовірностей у вузланащадка.

В БМД дуже важливим є факт не тільки наявності певних зв'язків між вузлами, але і відсутність таких зв'язків там, де, за думкою ОПР, вони не мають бути.

3 практичної точки зору це означає незалежність ймовірнісних величин, що суттєво впливає на перерахунок їх ймовірностей.

Приклад на рис. 4 показує БМД, призначення якої полягає у послідовній згортці множини значень параметрів (ліва колонка вузлів) через проміжні характеристики (середня колонка) до показника якості зразка.

Досвід експерта враховується при створенні БМД у таких рішеннях:
- у визначенні структури БМД, тобто множини проміжних характеристик та множини ребер між вузлами;

- у визначенні апріорних розподілів імовірностей для всіх видів БМД.

Пояснимо п. 2 на прикладі.

Нехай для “Параметру 1" експерт для зручності його оцінювання визначив рівні $\mathrm{Bad}$ (поганий), Middle (середній) та Good (добрий) (рис. 4). 3 свого досвіду експерт очікує апріорне найбільш ймовірне середнє значення, менш імовірне - добре і як малоймовірне - погане. Виражаючи свою оцінку в числах, експерт одержує апріорний розподіл ймовірностей для вузла “Параметр 1", як показано на рис. 5. Оскільки ці числа виражають імовірності, їх сума має бути 1.

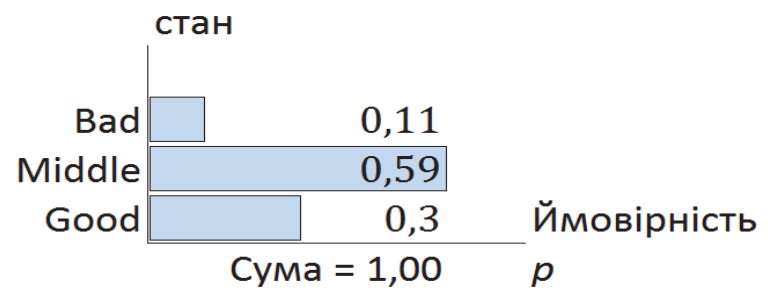

Рис. 5. Приклад експертного апріорного розподілу імовірностей для вузла БМД

Джерело: розроблено авторами.

Для вузлів, які мають предків, експерту задати розподіл апріорних імовірностей складніше. Так, для конкретності, для вузла "Характеристика 1" таблиця апріорних ймовірностей може мати вигляд як в табл. 1. 
Приклад розподілу апріорних ймовірностей для вузла "Характеристика 1"

\begin{tabular}{|l|c|c|c|c|c|c|c|}
\hline \multicolumn{2}{|l|}{$\begin{array}{l}\text { Стани } \\
\text { "Параметру 1" }\end{array}$} & \multicolumn{2}{|c|}{ Good } & \multicolumn{3}{c|}{ Middle } & \multicolumn{3}{c|}{ Bad } \\
\hline $\begin{array}{l}\text { Стани } \\
\text { "Параметру 2" }\end{array}$ & Good & Bad & Good & Bad & Good & Bad \\
\hline $\begin{array}{l}\text { Стани } \\
\text { "Характеристики 1" }\end{array}$ & Good & 0,9 & 0,5 & 0,75 & 0,6 & 0,5 & 0,1 \\
\cline { 2 - 9 } & Bad & 0,1 & 0,5 & 0,25 & 0,4 & 0,5 & 0,9 \\
\hline
\end{tabular}

Джерело: розроблено авторами.

Для заповнення табл. 1 експерту потрібно визначити загальну кількість значень, яка пропорційна кількості станів у всіх вузлів-предків і у вузланащадка. Це є ілюстрацією того факту, що при створенні структури БМД та визначенні властивостей вузлів потрібно пам'ятати про навантаження на експерта. Якщо в структурі БМД присутні вузли, у яких більше трьох предків та/або у вузлів завдані більше трьох станів, то таблиці апріорних імовірностей стають важкими для заповнення експертом внаслідок надмірного зростання їх розмірності. Визначення структури БМД, таким чином, $є$ відповідальним кроком, від якості виконання якого залежить якість майбутніх рішень.

Після виконання підготовчих операцій, описаних вище, можна за допомогою БМД допомогти ОПР відповісти на ряд важливих запитань.

Перше з них: яка очікувана ймовірність бажаного значення показника якості зразка ОВТ при врахуванні тільки апріорних імовірностей його параметрів?

Відповідь на це питання полягає в обчисленні повної ймовірності кожного вузла-нащадка, з його вузлами-предками, які утворюють згортку (так звані конвергентні вузли).
Друге важливе питання, на яке дає відповідь БМД, полягає к тому, що вона дозволяє відстежити зміну ймовірності позитивного значення "Показника якості зразка" за умови одержання виміряних (досліджених) значень “Параметру 1"... “Параметру 4", або любої їх частини.

I третє важливе питання, на яке дає відповідь БМД, полягає у можливості оцінити, з якою ймовірністю впливають параметри та характеристики БМД на одержання бажаного кінцевого результату вузла "Показник якості зразка". Тобто в цьому випадку аналіз виконується в, так би мовити, зворотньому напрямку - від "Показника якості зразка" до характеристик, а від них - до параметрів. Математично це виконується застосуванням формули Байєса (4).

Обчислення описаних вище ймовірностей вручну можливо тільки для простих БМД, із складністю не вище зображеної на рис. 5. Практично використовувані БМД значно складніші і їх математична підтримка неможлива без застосування комп'ютерних технологій. Для ї моделювання створено ряд програмних застосувань, перелік яких наведено в табл. 2. Як ілюстрацію наведемо на рис. 6 результати моделювання прикладу рис. 5 в середовищі Bayes Fusion Genia 2.4.

Таблиця 2

Програмні застосування для моделювання Байєсівської мережі довіри

\begin{tabular}{|c|c|c|c|}
\hline $\begin{array}{c}\text { Назва } \\
\text { програмного } \\
\text { продукту }\end{array}$ & Розробник & Країна & Категорія \\
\hline Agena Risk & Agena, Ltd. & Велика Британія & Комерційна \\
\hline Bayesian Lab & Bayesia S.A.S. & Франція & Вільна з обмеженнями \\
\hline Bayes Server & Bayes Server, Ltd. & Велика Британія & Комерційна \\
\hline Genie Modeler & BayesFusion, LLC & США & $\begin{array}{l}\text { Версія Аcademic вільна } \\
\text { для дослідницьких } \\
\text { та навчальних цілей }\end{array}$ \\
\hline Hugin Explorer & Hugin Expert A/S & Данія & Комерційна \\
\hline Netica & Norsys & Канада & $\begin{array}{l}\text { Вільна } \\
\text { з обмеженнями }\end{array}$ \\
\hline
\end{tabular}

Джерело: розроблено авторами. 


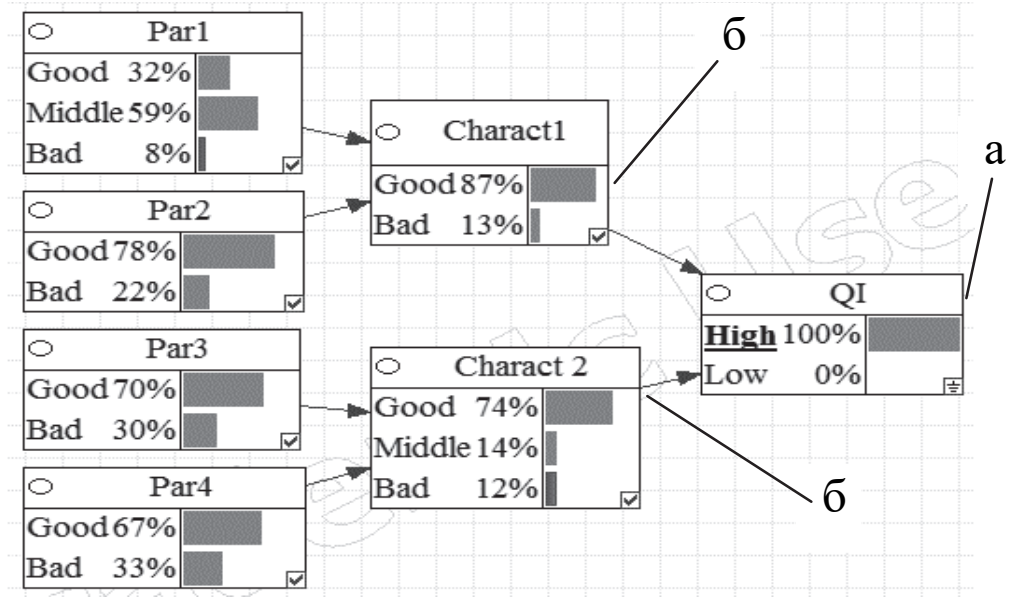

Рис. 6. Результат моделювання БМД в застосунку Bayes Fusion Genia 2.4: a - означення результату High $=100 \%$;

б - приклади розрахунку правдоподібності результатів Good у характеристик Джерело: розроблено авторами.

Після того, як користувач моделі рис. 6 задає означення High $=100 \%$ вузла QI (аналог вузла "Показник якості зразка" на рис. 5), відбувається автоматичне оновлення розподілів ймовірностей на всіх вузлах моделі.

Таким чином, для оцінки конкуруючих подібних зразків ОВТ за ймовірнісними критеріями, потрібно виконати наступне.

Використовуючи досвід експертів, побудувати модель Байєсівської мережі довіри, в якій будуть враховані причинно-наслідкові та логічні зв'язки між параметрами ОВТ та інтегральним показником якості зразка. Досвід експертів враховується також у визначенні апріорних розподілів ймовірностей для вузлів БМД. Для створення моделі БМД раціонально використовувати доступне програмне забезпечення $з$ наведених у табл. 2 .

Для кожного $з$ порівнюваних зразків визначити множини результатів визначення іх параметрів $R=\left\{r_{i}\right\} \mid i \in[1 \ldots N]$, яким відповідають вузли параметрів на моделі БМД. По черзі для кожного зразка внести значення цих параметрів як означення вузлів-параметрів в БМД. Зафіксувати одержаний результат як ймовірність $p^{+}$позитивного значення показника якості зразка. Таким чином, модель БМД тут виступає як програмно-алгоритмічний засіб згортки множини параметрів зразка ОВТ до розподілу ймовірностей інтегрального показника якості.

3 множини порівнюваних зразків ОВТ вибирається той, для якого $p^{+}=\max \left(p_{j}^{+}\right) \mid j \in[1 \ldots M]$. Описана процедура прийняття рішення про вибір застосовується в ситуації недостатності статистичних даних, коли упевненість ОПР в правильності прийнятого рішення базується на досвіді експертів. Але повторення цього вибору з часом дозволяє накопичити певні статистичні дані. Обсяг цих даних споча- тку не $є$ репрезентативним, але, по мірі збільшення їх обсягу ступінь репрезентативності збільшується. Врахування статистики при використанні БМД можливо шляхом періодичного “навчання” БМД на цих даних. Це навчання виконується 3 використанням певних статистичних методів, наприклад, методу Петера-Кларка. [20] Результатом таких навчань $\epsilon$ корекція як структури БМД (поява або видалення окремих вузлів та ребер графу моделі), так і таблиць розподілів апріорних ймовірностей вузлів. Доведена [20] сходимість цих корекцій до практично стабільного стану БМД, який статистично відповідає використаним даним.

\section{Висновки}

Запропонована методика дозволяе при конкурентному виборі зразків ОВТ порівнювати їх за інтегральним показником якості, який визначається шляхом ймовірнісного моделювання 3 допомогою байєсівської мережі довіри.

Показники якості, визначені за допомогою БМД, можуть враховувати результати порівняльного експериментального оцінювання зразків ОВТ, в тому числі за результатами випробувань, і можуть бути корисними при формуванні сертифікаційних базисів ОВТ.

Традиційні методи багатокритеріального вибору зразка ОВТ за критерієм порівняльної якості множини конкуруючих зразків не вільні від впливу суб'єктивного ставлення ОПР до вибору як самого методу, так і кількісних параметрів його практичного застосування. Крім того, практично у всіх них відбувається неявний перехід від апріорно нечіткого початкового багатокритеріального формулювання завдання вибору до однокритеріального, що можна трактувати як методологічний недолік. 
Наявність доступного програмного забезпечення для моделювання БМД відкриває можливість оперативної оцінки зміни ймовірностей параметрів та характеристик зразків ОВТ при одержанні ре- зультатів їх технічної діагностики, а також створювати спеціалізовані програмні системи, які подібні оцінки могли б виконувати найбільш зручним для ОПР способом.

\section{Список літератури}

1. Про воєнну доктрину України : Указ Президента України від 24 верес. 2015 р. № 555/2015. URL: https://zakon.rada.gov.ua/laws/show/555/2015 (дата звернення: 09.02.2021).

2. ДСТУ 2925-94. Якість продукції. Оцінювання якості. Терміни та визначення. [Чинний від 1994-12-14]. Вид. офіц. Київ, 1995. 34 с. (Держстандарт України).

3. ДСТУ 3278-95. Система розроблення та поставлення продукції на виробництво. Основні терміни та визначення. [Чинний від 1995-12-27]. Вид. офіц. Київ, 1996. 59 с. (Держстандарт України).

4. Про оборонні закупівлі : Закон України від 17 лип. 2020 р. № 808-IX. Відомості Верховної Ради Украӥни, 2020, № 10-11. URL: https://zakon.rada.gov.ua/laws/show/808-20\#Text (дата звернення: 09.02.2021).

5. Про публічні закупівлі : Закон України від 02 січ. 2020 р. № 1026-IX. Відомості Верховної Ради України, 2021, № 4, URL: https://zakon.rada.gov.ua/laws/show/922-19\#Text (дата звернення: 09.02.2021).

6. ДСТУ 3021-95. Випробування і контроль якості продукції. Терміни та визначення. [Чинний від 1995-02-28]. Вид. офіц. Київ : Держстандарт України, 1995. 41 с.

7. ДСТУ 3974:2000. Система розроблення та поставлення продукції на виробництво. Правила виконання дослідноконструкторських робіт. Загальні положення. [Чинний від 2000-11-27]. Вид. офіц. Київ, 2001. 38 с. (Держстандарт України).

8. Про затвердження Авіаційних правил України, Ч. 21 “Сертифікація повітряних суден, пов'язаних з ними виробів, компонентів та обладнання, а також організацій розробника та виробника” АПУ-21(Part-21) : Наказ Держ. авіаційної служби України від 26 квіт. 2019 р. № 529. URL: http://search.ligazakon.ua/1_doc2.nsf/link1/RE33514.html (дата звернення: 10.02.2021).

9. Про затвердження Правил сертифікації повітряних суден, пов'язаних з ними виробів, компонентів та обладнання, які належать до військової техніки, а також організацій розробника та виробника : Наказ мінстра оборони України від 03 лист. 2016 р. № 586. URL: https://zakon.rada.gov.ua/laws/show/z1603-16\#Text (дата звернення: 10.02.2021).

10. Егорушкин С. Оружейный рынок. Кто побеждает в мировой конкурентной борьбе? Капитал страны. Федеральное интернет издание : веб-сайт. URL://kapital-rus.ru/articles/article/prodaji_orujiya (дата звернення: 08.02.2021).

11. Федяева В. К., Омельяновский В. В., Реброва О. Ю. Многокритериальный анализ как инструмент поддержки принятия решений: обзор методов и возможностей их применения в оценке технологий здравоохранения. Медищинские технологии. Оченка и выбор. 2014. № 2. С. 30-35. URL: https://pps.ranepa.ru/Publication2/2014/f99ba2bc-cbbf-e611-80d0005056a06105/573b6440d8fbe.pdf (дата звернення: 08.02.2021).

12. Hurwicz L. The generalized Bayes minimax principle: Acriterion for decision making underuncertainty. Cowles commission discussion paper: Statistics, 355. 1952. URL: https://cowles.yale. edu/sites/default/files/files/pub/cdp/s-0355.pdf (дата звернення: 08.02.2021).

13. Savage L. J. The Theory of Statistical Decision. Journal of the American Statistical Association. 1951. № 46(253). P. 55-67.

14. Семенов С. С., Харчев В. И., Иоффин А. И. Оценка технического уровня образцов вооружения и военной техники. Москва : Радио и связь, 2004. 552 с.

15. Saati T. L. The analytic hierarchy process: planning, priority setting, recourse allocation. New York : McGraw-Hill, 1980. $287 \mathrm{p}$.

16. Саати Т. Л. Об измерении неосязаемого. Подход к относительным измерениям на основе главного собственного вектора матрицы парных сравнений. Электронный журнал Cloud of Science. 2015. № 1(2). P. 6-39. URL: http://cloudofscience.ru/ (дата звернення: 08.02.2021).

17. Гельфанд И. М. Лекции по линейной алгебре : учебное пособие. Москва : Добросвет, КДУ, 2009. 320 с.

18. Огурцов А. П. Метафизика и способы обоснования исчисления вероятностей. Идеи и идеалы. 2010. № 4(6). C. 110-133. URL: https://cyberleninka.ru/article/n/metafizika-i-sposoby-obosnovaniya-ischisleniya-veroyatnostey-razroznennyezametki/viewer (дата звернення: 08.02.2021).

19. Чайковский Ю. В. Что такое вероятность. Эволюция понятия (от древности до Пуассона) Историкоматематические исследования. Вторая серия. 2001. № 6(41). С. 34-57.

20. Вентцель Е. С. Теория вероятностей: учеб. для вузов. 6-е изд. стер. Москва : Высшая школа, 1999. 576 с.

21. Тулупьев А. Л., Николенко С. И., Сироткин А. В. Байесовские сети : Логико-вероятностный подход. СанктПетербург : Наука, 2006. 607 с.

Надійшла до редколегії 02.06.2021 Схвалена до друку 13.07.2021

\author{
Відомості про авторів: \\ Камак Юрій Олександрович \\ начальник науково-дослідного управління \\ Державного науково-дослідного інституту випробувань \\ і сертифікації озброєння \\ та військової техніки, \\ Чернігів, Україна \\ https://orcid.org/0000-0003-1953-411X
}

\author{
Information about the authors \\ Yurii Kamak \\ Chief of Scientific Research Management \\ of State Scientific Research Institute \\ of Armament and Military Equipment Testing \\ and Certification, \\ Chernihiv, Ukraine \\ https://orcid.org/0000-0003-1953-411X
}


Нестеренко Сергій Олександрович

кандидат технічних наук доцент провідний науковий співробітник Державного науково-дослідного інституту випробувань і сертифікації озброєння та військової техніки, Чернігів, Україна https://orcid.org/0000-0002-4721-6883

Рудніченко Сергій Володимирович провідний науковий співробітник Державного науково-дослідного інституту випробувань і сертифікації озброєння та військової техніки, Чернігів, Україна https://orcid.org/0000-0002-1810-142X

\section{Чигрин Роман Миколайович}

кандидат технічних наук провідний науковий співробітник Харківського національного університету

Повітряних Сил ім. І. Кожедуба,

Харків, Україна

https://orcid.org/0000-0002-9996-1367

\section{Sergii Nesterenko}

Candidate of Technical Sciences Associate Professor Lead Researcher of State Scientific Research Institute of Armament and Military

Equipment Testing and Certification, Chernihiv, Ukraine https://orcid.org/0000-0002-4721-6883

\section{Sergii Rudnichenko}

Lead Researcher of State Scientific Research Institute of Armament and Military

Equipment Testing and Certification,

Chernihiv, Ukraine

https://orcid.org/0000-0002-1810-142X

\section{Roman Chygryn}

Candidate of Technical Sciences Lead Researcher

of Ivan Kozhedub Kharkiv

National Air Force University,

Kharkiv, Ukraine

https://orcid.org/0000-00029996-1367

\section{ПРИМЕНЕНИЕ ВЕРОЯТНОСТНЫХ СЕТЕЙ ДОВЕРИЯ ДЛЯ МНОГОКРИТЕРИАЛЬНОГО ОЦЕНИВАНИЯ ПОКАЗАТЕЛЕЙ КАЧЕСТВА ВООРУЖЕНИЯ И ВОЕННОЙ ТЕХНИКИ}

Ю.А. Камак, С.А. Нестеренко, С.В. Рудниченко, Р.Н. Чигрин

В статье проводится анализ процесса конкурентного выбора образиов вооружения и военной техники с иелью выбора образиа вооружения и военной техники, наилучшего за определенным показателем качества из ряда альтернативных. Проведен анализ математического аппарата решения поставленной проблемы и предложено использования аппарата байєсовской сети доверия для решения задачи выбора качественного образиа вооружения и военной техники. Приведен анализ программных средств для моделирования байєсовских сетей доверия. Предложена прочедура принятия решения относительно выбора образиа по вероятностным критериям в условиях недостаточной определенности.

Ключевые слова: вооружение и военная техника, показатель качества, лицо, принимающее решение, байєсовская сеть доверия.

\section{APPLICATION OF PROBABLE NETWORKS OF CONFIDENCE FOR MULTI-CRITERIONAL ASSESSMENT OF QUALITY INDICATORS OF WEAPONS AND MILITARY EQUIPMENT}

\section{Yu. Kamak, S. Nesterenko, S. Rudnichenko, R. Chygryn}

The acceptance of a sample of weapons and military equipment for operation in the Armed Forces of Ukraine is a complex process that requires a large number of robots to justify its characteristics. The key problem in the selection of characteristics is to substantiate such characteristics that would ensure the ability of a model of weapons and military equipment to guarantee the achievement of the assigned combat objectives during its regular use. On the other hand, efficiency is a consequence of the sufficient quality of the model of weapons and military equipment, that is, the sample must meet a high technical level. The solution to this problem must also take into account the requirements of regulatory documents, domestic and international standards. The article analyzes the process of competitive selection of weapons and military equipment in order to select a model of weapons and military equipment, the best for a certain quality indicator from a number of alternative ones. The analysis of the mathematical apparatus for solving the problem posed is carried out and the use of the apparatus of the Bayesian network of trust is proposed to solve the problem of choosing a high-quality model of weapons and military equipment. The analysis of software tools for modeling Bayesian trust networks is presented. A procedure for making a decision regarding the choice of a sample based on probabilistic criteria in conditions of insufficient certainty is proposed. The availability of available software for modeling the Bayesian network of trust opens up the possibility of a quick assessment of changes in the probabilities of parameters and characteristics of weapons and military equipment when receiving the results of their diagnostics, as well as creating specialized software systems that could perform such assessments in the most convenient way for a decision maker.

Keywords: weapons and military equipment, quality indicator, decision maker, Bayesian trust network. 